\title{
Intestinal Absorption of Immunoglobulins by Newborn Infants
}

\author{
LEELA IYENGAR and R. J. SELVARAJ \\ From the National Institute of Nutrition, Indian Council of Medical Research, Jamai-Osmania, Hyderabad, India
}

\begin{abstract}
Iyengar, L., and Selvaraj, R. J. (1972). Archives of Disease in Childhood, 47, 411. Intestinal absorption of immunoglobulins by newborn infants. Intestinal absorption in newborn infants of immunoglobulins present in colostrum was studied by measuring the concentrations of immunoglobulins IgA, IgG, and IgM in cord blood and following the changes in the serum of the infant on the 5th day after birth. In infants who did not receive colostrum, a marked fall in IgG levels was observed on the 5th day after birth as compared to levels at birth. The concentrations of IgA and IgM showed marginal changes. In contrast, colostrumfed infants showed significant increases in the concentration of IgG. Levels of all 3 immunoglobulins on the 5th day were significantly higher in the serum of colostrumfed infants as compared to those who did not receive colostrum. It is suggested that immunoglobulins present in colostrum are to some extent absorbed from the intestinal tract of newborn infants, and this may have some physiological significance in the resistance to infection during the early neonatal period.
\end{abstract}

Until recently it was widely believed that the mammalian fetus was incapable of immunological response. In recent years, however, evidence has accumulated to show that the fetus is immunologically competent (McCracken and Shinefield, 1965). From very early pregnancy, the human fetus is capable of synthesizing its own immunoglobulins (IgG, M, and A) when exposed to intrauterine infections like congenital syphilis (Alford et al., 1967), toxoplasmosis, or viral infection (Stiehm, Ammann, and Cherry, 1966). Though capable of responding to infection by synthesizing its own antibodies, the fetus receives its passive immunity from transplacental transfer of IgG from the mother. This maternally derived IgG shows a progressive fall from birth till 6 weeks of age, after which period a steady increase is seen due to synthesis of the immunoglobulin by the infant, till it reaches the adult level at the age of 3 years. The infant is born with very low levels of $\operatorname{IgA}$ and IgM. These two immunoglobulins appear in the infant's blood in the neonatal period and show a progressive increase till 9 months of age (West, Hong, and Holland, 1962).

It is of major interest to find out whether the human infant can absorb immunoglobulins from

Received 14 October 1971. maternal colostrum, a rich source of antibodies, before it forms its own antibodies. Though this has been shown to occur in ruminants (Deutsch and Smith, 1957) and mice (Morris, 1964), the reports on the capability of absorption of intact protein molecules in newborn infants is equivocal (Ratner, Jackson, and Gruehl, 1927; McKhann and Kapnick, 1938; Leissring, Anderson, and Smith, 1962). An investigation was, therefore, undertaken to determine immunoglobulin levels in the sera of infants at birth and after feeding colostrum.

\section{Material and Methods}

Paired samples of cord and maternal blood were collected from 31 mothers delivered at 40 weeks. All deliveries were normal and uncomplicated. 18 of these mothers were allowed to feed colostrum to their infants from the 2nd day after delivery (counting the day of delivery as day 1) followed by milk from the 4th day after delivery. The remaining 13 infants did not receive colostrum, but were instead bottle-fed with formula milk till the 4th day, followed by breast milk subsequently. The colostrum from the mothers of these infants was expressed and discarded.

Blood samples from all these infants were obtained on the 5 th day by heel puncture and the sera separated. Samples of colostrum and breast milk were collected by manual expression on the 2 nd and 5 th day, respectively, 
in sterile containers. All the samples were kept frozen at $-20^{\circ} \mathrm{C}$ till analysis.

The major immunoglobulin fractions $G, A$, and $M$ were determined in all the samples by the single radial immunodiffusion technique of Mancini as described by Fahey and McKelvey (1965). Agar plates impregnated with monospecific goat antisera for human $\operatorname{IgA}, M$, and G (purchased from Hyland, Travenol Laboratory Inc., Los Angeles) were prepared on glass slides of the size $10 \times 10 \mathrm{~cm}$. After the agar had set, wells were drilled at $1 \mathrm{~cm}$ intervals. Samples were assayed at 3 different levels, along with duplicates of 4 different levels of reference serum (gift from WHO immunological reference centre-Batch No. 67/97) on the same plate, thereby minimizing the variations due to differences in plates. The concentrations of immunoglobulins in the samples are expressed as percentages of reference serum. The statistical analysis of the cord serum versus 5thday baby's serum were done by student's ' $t$ ' test on paired figures.

\section{Results}

IgG levels in cord serum were lower than those of the maternal serum, the values for the two being $105 \%$ and $141 \%$, respectively, of the reference serum $(P<0.01)$. Colostrum IgG concentration was not different from serum IgG concentration while the concentration in milk was very low, being on the average only $11 \cdot 7 \%$ of the reference serum $(P<0.001)$.

Cord IgA and IgM levels were very low, being only $17 \cdot 2 \%$ and $33.2 \%$ of the reference serum concentrations, respectively $(12.4 \%$ and $27.5 \%$ of the maternal serum levels). In colostrum, very high levels of IgA (15 times that of reference serum) were found, while the 5th-day milk showed a dramatic decrease to approximately half of the reference serum level. IgM levels in colostrum were $157 \%$ and in milk $46 \%$ of the reference serum (Table I). All these differences were statistically significant.

The mean concentrations of $\operatorname{IgA}$ and $\mathrm{IgG}$ in cord serum of infants at birth assigned to the colostrumfed group tended to be lower than levels in infants assigned to the milk group, though the differences were not statistically significant. Strictly alternate cases were assigned to the 2 groups, there being no selection.

No correlation was seen between the birthweights of infants and the concentration of any of the cord serum immunoglobulins.

The effects of feeding colostrum on serum immunoglobulin levels of infants on the 5 th day after birth are shown in Tables II, III, and IV. While the levels of IgG in serum of infants who did not receive colostrum showed a reduction to the extent of $24 \%$ on the 5 th day as compared to levels at

TABLE I

Immunoglobulin Levels in Cord and Maternal Sera, Colostrum, and Milk (Expressed as \% of Reference Serum Levels)

\begin{tabular}{c|c|c|c}
\hline $\begin{array}{c}\text { Immunoglobulin } \\
\text { Fraction }\end{array}$ & Cord Serum & Maternal Serum & Colostrum \\
\hline IgG (30) & $105 \cdot 0 \pm 5 \cdot 60$ & $140 \cdot 0 \pm 6 \cdot 72$ & $97 \cdot 0 \pm 22 \cdot 14$ \\
IgA (30) & $17 \cdot 2 \pm 3 \cdot 13$ & $137 \cdot 0 \pm 9 \cdot 41$ & $1503 \cdot 0 \pm 180 \cdot 94$ \\
IgM(30) & $33 \cdot 2 \pm 4 \cdot 89$ & $135 \cdot 0 \pm 9 \cdot 86$ & $\begin{array}{c}11 \cdot 7 \pm 1 \cdot 58 \\
41 \cdot 8 \pm 9 \cdot 92\end{array}$ \\
\hline
\end{tabular}

Note: Values are means + SEM

The numbers of observations are given in parentheses.

TABLE II

Effect of Colostrum Feeding on Serum IgG Levels

(Expressed as \% of Reference Serum Levels)

\begin{tabular}{|c|c|c|c|c|}
\hline Group & Cord Serum (CS) & $\begin{array}{c}\text { 5th Day } \\
\text { Infant's Serum } \\
\text { (IS) }\end{array}$ & 'P' Value CS vs IS & Difference (IS-CS) \\
\hline $\begin{array}{l}\text { Colostrum-fed (CF) } \\
\text { Bottle-fed (BF) } \\
\text { 'P' value for CF vs BF }\end{array}$ & $\begin{array}{c}99 \cdot 0 \pm 8 \cdot 54 \\
(18) \\
114 \cdot 5 \pm 5 \cdot 47 \\
(12) \\
0 \cdot 1\end{array}$ & $\begin{array}{c}112 \cdot 5 \pm 11 \cdot 52 \\
(18) \\
89 \cdot 6 \pm 8 \cdot 86 \\
(12) \\
0 \cdot 1\end{array}$ & $\begin{array}{l}<0.05 \\
<0.01 \\
-\end{array}$ & $\begin{array}{c}+13 \cdot 5 \pm 10 \cdot 44 \\
(18) \\
-25 \cdot 0 \pm 7 \cdot 81 \\
(12) \\
<0 \cdot 001\end{array}$ \\
\hline
\end{tabular}

Note: Values are means \pm SEM.

The numbers of observations are given in parentheses. 
TABLE III

Effect of Colostrum Feeding on Serum IgA Levels

(Expressed as \% of Reference Serum Levels)

\begin{tabular}{|c|c|c|c|c|}
\hline Group & Cord Serum (CS) & $\begin{array}{c}\text { 5th Day } \\
\text { Infant's Serum } \\
\text { (IS) }\end{array}$ & 'P' for CS vs IS & Difference (IS-CS) \\
\hline $\begin{array}{l}\text { Colostrum-fed (CF) } \\
\text { Bottle-fed (BF) } \\
\text { 'P' value for CF vs } B F\end{array}$ & $\begin{array}{c}14 \cdot 7 \pm 4 \cdot 14 \\
(15) \\
21 \cdot 3 \pm 5 \cdot 60 \\
(12) \\
0 \cdot 1\end{array}$ & $\begin{array}{c}31 \cdot 6 \pm 7 \cdot 38 \\
(15) \\
17 \cdot 6 \pm 3 \cdot 59 \\
(12) \\
0 \cdot 1\end{array}$ & $\begin{array}{c}<0.001 \\
0.1 \\
-\end{array}$ & $\begin{array}{c}+16 \cdot 3 \pm 5 \cdot 56 \\
(15) \\
-3 \cdot 7 \pm 4 \cdot 15 \\
(12) \\
<0 \cdot 01\end{array}$ \\
\hline
\end{tabular}

Note: Values are means \pm SEM.

The number of observations are given in parentheses.

TABLE IV

Effect of Colostrum Feeding on Serum IgM Levels

(Expressed as \% of Reference Serum Levels)

\begin{tabular}{|c|c|c|c|c|}
\hline Group & Cord Serum (CS) & $\begin{array}{c}\text { 5th Day } \\
\text { Infant's Serum } \\
\text { (IS) }\end{array}$ & 'P' for CS vs IS & Difference (IS-CS) \\
\hline $\begin{array}{l}\text { Colostrum-fed (CF) } \\
\text { Bottle-fed (BF) } \\
\text { 'P' value for CF vs } B F\end{array}$ & $\begin{array}{c}36 \cdot 0 \pm 4 \cdot 89 \\
(14) \\
38 \cdot 0 \pm 6 \cdot 34 \\
(13) \\
0 \cdot 1\end{array}$ & $\begin{array}{c}54 \cdot 0 \pm 9 \cdot 23 \\
(14) \\
39 \cdot 4 \pm 6 \cdot 96 \\
(13) \\
0 \cdot 1\end{array}$ & $\begin{array}{c}<0.05 \\
0.1 \\
-\end{array}$ & $\begin{array}{c}+18 \cdot 0 \pm 6 \cdot 82 \\
(14) \\
+1 \cdot 5 \pm 4 \cdot 48 \\
(13) \\
P<0 \cdot 05\end{array}$ \\
\hline
\end{tabular}

Note: Values are means + SEM.

The numbers of observations are given in parentheses.

birth $(P<0.01)$, the levels in colostrum-fed infants showed a small rise from the initial levels. The differences in IgG levels on the 5th day between the 2 groups was highly significant ( $P$ $<0.001$ ) (Table II).

Serum IgA levels in the infants on the 5th day were not different from those at birth in the bottlefed group, but in the colostrum-fed infants there was a twofold increase on the 5th day (Table III). Similarly IgM levels also showed a significant increase to the extent of $50 \%$ in the colostrum-fed infants, there being no change in the bottle-fed group (Table IV).

\section{Discussion}

These results show that IgG levels in cord blood are slightly lower than those in the maternal serum - an observation similar to that of Allansmith, McClennan, and Butterworth (1969) and of Chandra, Guha, and Ghai (1970). The concentrations of IgM and IgA in cord blood are, however, considerably lower than the levels in maternal serum. These data indicate that the transfer of these immunoglobulins across the placenta is not similar, there being a greater transfer of IgG than the other two. There have been reports indicating that IgG is transferred preferentially across the placenta (Gitlin et al., 1964). The absolute values seen here are higher than those reported by Allansmith et al. (1969) and Stiehm and Fudenberg (1966).

There have been some earlier studies by Ratner et al. (1927), McKhann and Kapnick (1938), and Leissring et al. (1962), where attempts have been made to assess the ability of the newborn human infant to absorb immunologically intact proteins from the intestinal lumen. The results of these studies have, however, been conflicting, while in none have the concentrations of individual immunoglobulins been determined as in the present investigation.

The marked fall in IgG levels in bottle-fed infants observed here is similar to that reported by Allansmith et al. (1969) who had also observed that on the 5th day after birth, IgG levels showed a decrease to the extent of $20-40 \%$ of the levels at birth. However, colostrum-fed infants in the present study actually showed a small increase in IgG levels on the 5th day as compared to the levels at birth. These observations suggest that the reduc- 
tion of IgG levels brought about as a result of catabolism (as is observed in bottle-fed infants) was probably compensated by the intestinal absorption of IgG from the colostrum.

Similarly, bottle-fed infants in the present series showed only marginal changes in serum IgA and $M$ levels on the 5th day in contrast to the greater increases (IgM by $50 \%$ and IgA by $118 \%$ of basal levels on 5th day) in colostrum-fed infants, suggesting that both these immunoglobulins are absorbed in significant quantities from the gastrointestinal tract of newborn infants.

It may be argued that changes in plasma volume arising as a result of different amounts of sodium intake in infants fed cow's milk and colostrum could have contributed to these differences in the levels of immunoglobulins. The differences, however, appear to be too wide to support this possibility.

The presence of high levels of $\operatorname{IgA}$ and $M$ in colostrum is well documented. However, the role of such high levels of IgA is not clearly understood in the human situation. It has been suggested by Warren et al. (1964) that such high levels of antibody in colostrum in humans possibly protect the intestinal tract from infection by lysing the infecting bacteria or neutralizing the toxins produced by them. In ruminants, colostrum feeding has a great protective action against infection. Calves deprived of colostrum in the first few days of life die of a- $\gamma$-globulinaemia. How far this is applicable to the human situation where the infant is immunologically competent at birth, is not clearly understood. The results of the present investigation indicate that there is a significant rise in all the immunoglobulin fractions in colostrum-fed infants, though the total amount absorbed appears to be only a small fraction of that present in the colostrum. This increase in serum immunoglobulins may still have a physiological significance in the early neonatal period when the infant has not yet built up antibody levels.
We thank Dr. C. Gopalan, Director, and Dr. S. G. Srikantia, Deputy Director, for their valuable suggestions in this investigation.

\section{REFERENCES}

Alford, C. A., Schaefer, J., Blankenship, W. J., Straumfjord, J. Y., and Cassady, G. (1967). A correlative immunologic, microbiologic and clinical approach to diagnosis of acute and chronic infection in new born infants. New England fournal of Medicine, 277, 437.

Allansmith, M. R., McClennan, B. H., and Butterworth, M. (1969). Individual patterns of immunoglobulin development in ten infants. Fournal of Pediatrics, 75, 1231.

Chandra, R. K., Guha, D. K., and Ghai, O. P. (1970). Serum immunoglobulins in the newborn. Indian fournal of Pediatrics, 37, 361 .

Deutsch, H. F., and Smith, V. R. (1957). Intestinal permeability to proteins in the newborn herbivore. American fournal of Physiology, 191, 271.

Fahey, J. L., and McKelvey, E. M. (1965). Quantitative determination of serum immunoglobulins in antibody-agar plates. fournal of Immunology, 84, 84.

Gitlin, D., Kumate, J., Urrusti, J., and Morales, C. (1964). The selectivity of the human placenta in the transfer of plasma proteins from mother to fetus. Fournal of Clinical Investigation, 43, 1938.

Leissring, J. C., Anderson, J. W., and Smith, D. W. (1962). Uptake of antibodies by the intestine of the newborn infant. American fournal of Diseases of Children, 103, 160.

McCracken, G. H., Jr., and Shinefield, H. R. (1965). Immunoglobulin concentrations in newborn infants with congenital cytomegalic inclusion disease. Pediatrics, 36, 933.

McKhann, C. F., and Kapnick, I. (1938). Immunity and susceptibility to disease in early infancy. Fournal of Pediatrics, 13, 907.

Morris, J. G. (1964). The transmission of antibodies and normal $\gamma$-globulins across the young mouse gut. Proceedings of the Royal Society. Series B. Biological Sciences, 160, 276.

Ratner, B., Jackson, H. C., and Gruehl, H. L. (1927). Transmission of protein hypersensitiveness from mother to offspring: role of colostrum. Fournal of Immunology, 14, 267.

Stiehm, E. R., Ammann, A. J., and Cherry, J. D. (1966). Elevated cord macroglobulins in the diagnosis of intrauterine infection. New England fournal of Medicine, 275, 971.

Stiehm, E. R., and Fudenberg, H. H. (1966). Serum levels of immune globulins in health and diseases: a survey. Pediatrics, 37, 715.

Warren, R. J., Lepow, M. L., Bartsch, G. E., and Robbins, F. C. (1964). The relationship of maternal antibody, breast feeding, and age to the susceptibility of newborn infants to infection with attentuated polioviruses. Pediatrics, 34, 4.

West, C. D., Hong, R., and Holland, N. H. (1962). Immunoglobulin levels from the newborn period to adulthood and in immunoglobulin deficiency states. Fournal of Clinical Investigation, 41, 2054

Correspondence to Dr. R. J. Selvaraj, National Institute of Nutrition, Jamai-Osmania, Hyderabad-7 (A.P.), India. 